\title{
STUDY OF THE APPLICATION OF A FLUIDODYNAMIC ANALYSIS FOR COOLING A CVT TRANSMISSION SYSTEM
}

\author{
Lucas Aragão de Assis ${ }^{\underline{a}}$, Leo Guedes Blanco ${ }^{-}$, Davi Pinheiro Santana , Pedro Bacillon \\ Ventinª ${ }^{\mathrm{a}}$ Júlio Cézar Chaves Câmara ${ }^{\mathrm{a}}$ \\ a , Centro Universitario SENAI CIMATEC, Brasil
}

\begin{abstract}
CFD analysis is a computational technology widely used in the study of dynamic processes that present fluid flow, seeking to predict their behavior and their heat transfer. Knowing that the power transmission from a CVT gearbox is based on friction transmission, raising the system temperature and, consequently, impacting its performance. In order to minimize these inconveniences generated by the operation of a CVT transmission system, the development of a fan through the analysis of the working temperature by the SolidWorks software is proposed. This article demonstrates the procedure applied from the idealization of the problem to the definition of the best solution applied to the prototype in question.
\end{abstract}

Keywords: BAJA SAE; CFD Analysis; CVT; Heat Transfer.

\section{ESTUDO DA APLICAÇÃO DE UMA ANÁLISE FLUIDODINÂMICA PARA ARREFECIMENTO DE UM SISTEMA DE TRANSMISSÃO CVT}

Resumo: A análise CFD é uma tecnologia computacional bastante empregada nos estudos de processos dinâmicos que apresentam escoamento de fluidos, buscando prever seu comportamento e a sua transferência de calor. Sabendo que a passagem de potência a partir de um câmbio CVT se baseia na transmissão por atrito, elevando a temperatura do sistema e, consequentemente, impactando no desempenho do mesmo. A fim de minimizar estes inconvenientes gerados pelo funcionamento de um sistema de transmissão CVT, é proposto o desenvolvimento de uma ventoinha através de análise da temperatura de trabalho por parte do software SolidWorks. O presente artigo demonstra o procedimento aplicado desde a idealização do problema até a definição da melhor solução aplicada ao protótipo em questão.

Palavras-chave: Análise CFD; BAJA SAE; Câmbio CVT; Transferência de calor. 


\section{INTRODUCTION}

The CVT gearbox, which means for continuously variable transmission, provides power transmission with an infinite gear ratio between two extreme limits, where the engine can be operated at the ideal operating point for economy or performance, as needed [1].

It consists of a system of pulleys and belts, where the motor pulley and the driven pulley are tapered, and equipped with a mechanism that varies their effective diameters, changing the transmission ratio in a continuous way automatically [2]. In this way, through the friction of the belt, the torque provided by the motor pulley is transmitted to the driven pulley, giving it to an axis. This friction, especially when the vehicle is stopped, generates heat, increasing the temperature of the system and interfering with its performance. The Figure 1 below it is possible to see the representation of a CVT gearbox simulating the one studied.

Figura 1. Representation of a CVT [3]

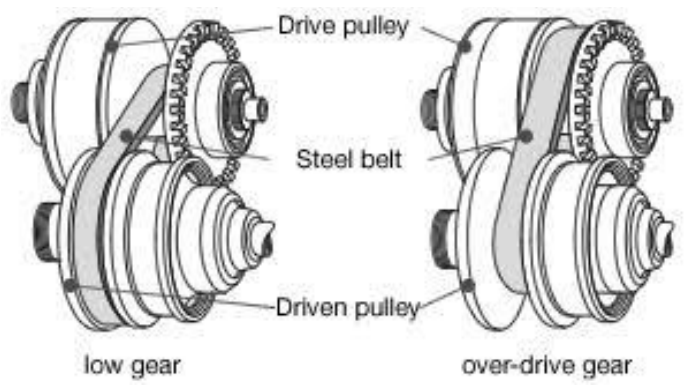

Although there are several ways to reduce temperatures, such as using air conditioners, using coolants, a Peltier cell, and others. However, due to its ease of installation, low cost and reduced space, fans are widely used, as in automotive radiators, in computer coolers and in the most diverse applications of industrial fans. Therefore, it is important to perform a computational analysis to verify the behavior of the fluid inside the enclosure, as well as the efficiency of the system before prototyping. For this verification, it is common to perform a CFD analysis.

Computational Fluid Dynamics (CFD) consists of a set of tools used in the analysis of systems involving fluid flow, heat and mass transfer and associated phenomena, such as chemical reactions, through numerical simulation [4]. For the simulation in question, the SolidWorks 2020 software will be used, through the Flow Simulation feature.

Regarding the type of fan to be used, since we need the incoming air to be directed backwards, focusing on the hot components that will be behind the fan, there are two more common geometries: the fan with flat fins, widely used in equipment exhaust gases, fumes, vapors and industrial odors, and the fan with concave fins, since this is found in air conditioning systems, evaporative condensers, hoods and cooling 
towers [5]. Therefore, these two types will be tested throughout the study in order to find the best option for cooling CVT.

Analyzing the mandatory coverage of the CVT gearbox, it was noticed that the heat dissipation inside it was ineffective without the use of any other component, causing a rapid and exacerbated increase in temperature, as can be seen in the prototype built by the BAJA team. from SENAI CIMATEC, CalangoTec, in 2019, where, due to overheating, there was a large expansion of the belt and consequent loss of transmission to the wheels. This problem can be observed in practical studies of similar equipment due also to the increase in slipping with the increase in temperature [5].

Due to the principle of operation of the gearbox and the absence of a clutch on the engine used by the prototype, when the vehicle is stopped and the engine is running, only the motor pulley rotates, generating friction on the belt and, consequently, heating the whole assembly. In this situation, a 100\% slip was found between the pulley and the belt, causing a case of maximum friction and, consequently, greater heat generation in the system. The heating caused ends up interfering in the original resistance and elasticity properties of the belt, compromising its durability and the performance of the vehicle, besides being able to cause the rupture of the same.

\section{METHODOLOGY}

To remedy the problem, a forced ventilation system was proposed, coupling a fan to the motor pulley. A priori, the system works with air inlet and outlet ducts and a fan attached to the gear pulley. Thus, aiming to solve the problem for the situation mentioned above, while the motor rotates, the fan was rotated, generating a centrifugal force and providing an air current inside the cover. As a consequence, there is the transfer of heat between the air and the pulley and belt assembly through the forced convection process, reducing the system temperature and providing better performance in the transmission of force and movement.

For a more assertive simulation, it was necessary to determine some boundary conditions for the analysis. As stated earlier, the simulations will be based on the situation where the vehicle is stopped, at idle, in which there is a $100 \%$ slip between the motor pulley and the belt and, consequently, the generation of heat. Table 1 below shows the initial parameters of the simulation.

Table 1. Initial parameters of the simulation

\begin{tabular}{|l|c|}
\hline Parameters & Values \\
\hline Engine angular speed (rad/s) & 157 \\
\hline Inlet duct diameter $(\mathbf{m m})$ & 50 \\
\hline Outlet duct diameter $(\mathbf{m m})$ & 50 \\
\hline
\end{tabular}




\section{Protective cover material}

Motor pulley temperature $\left(C^{\circ}\right)$
Aluminium

80

The first step was the modeling of a new CVT protective cover. The new cover was designed to be made of aluminum, different from the previous model that was made of steel and fiberglass. The air inlet duct will be positioned axially aligned with the motor pulley (circled in green), while the outlet duct will be located at the bottom of the cover (circled in red) aligned with the moved pulley. In addition, the air inlet and outlet ducts will be stretched with flexible pipes, so that there is a better positioning in the vehicle. In Figure 2 below it is possible to see the 3D CAD model of the new designed cover (A) and the 3D CAD model previously used in 2019 is observed (B).

Figure 2. 3D CAD model of the protect cover
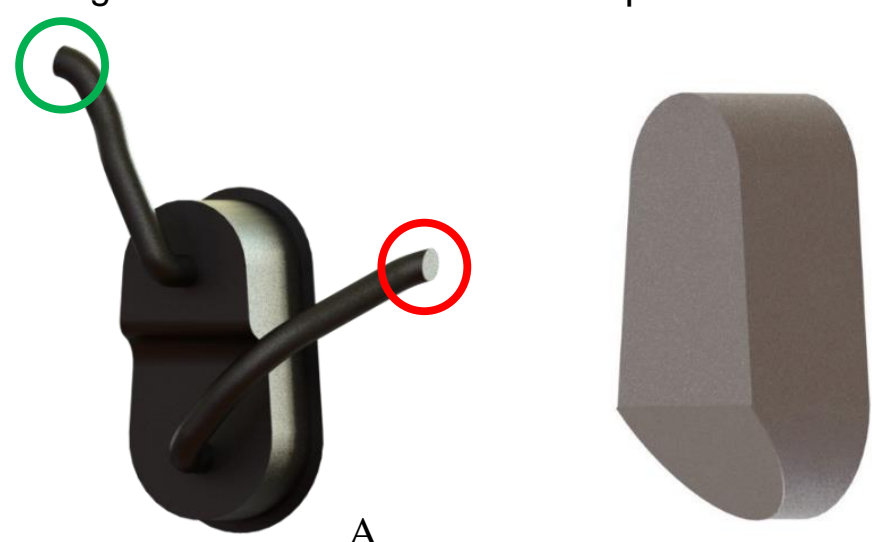

B

To continue the study, the two types of fans already mentioned were modeled; one with flat fins and one with concave fins, using different angles in relation to the fan axis. From these two models, studies were carried out regarding air flows inside the cover, observing its path and speed, in order to choose the most appropriate one. In Figure 3 below, you can see, on the left, the fan with concave fins (A), and, on the right, the fan with flat fins $(B)$.

Figure 3. Fan with concave fins (A) and the fan with flat fins (B)
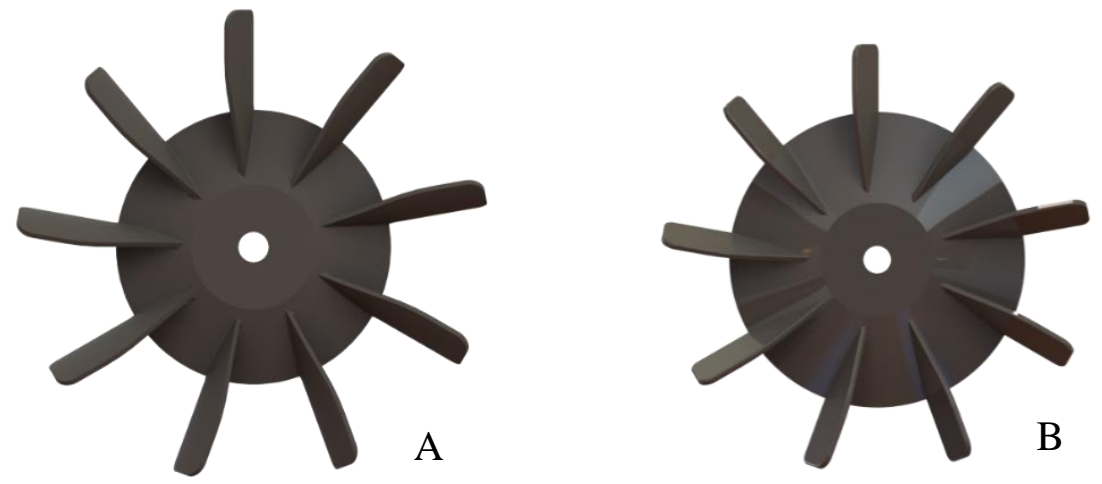
From there, 12 fans were modeled with fin amounts ranging from 7 to 18 , to check which would promote a more adequate flow to the system. For each fan, three simulations were performed with a physical time of 10 seconds, the exchange of heat from the air with the motor CVT, thus finding the cooling rate for each model.

After the simulations, the averages of each cooling rate were taken for each of the fans, in order to compare the results and find the most efficient model within the analyzed ones.

\section{RESULTS AND DISCUSSION}

As stated earlier, the first analyzes were made to define the ideal geometry of the fins, so that, from the flow analysis, the following results presented in Figure 3 were obtained.

Figure 3. Flow analysis using flat fins $A$ (left) and concave fins B (right)

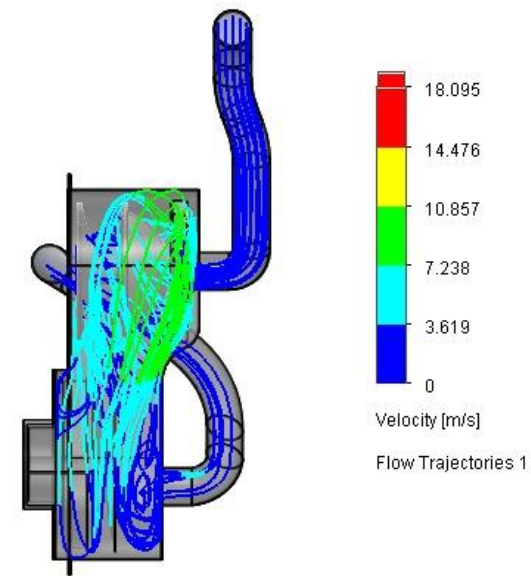

A

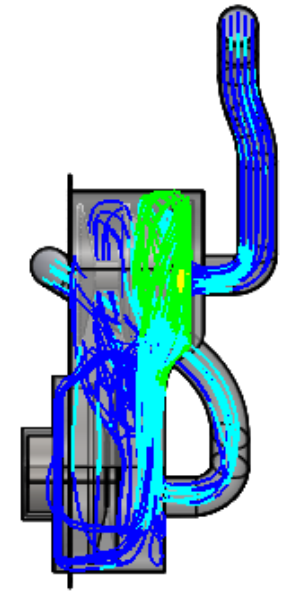

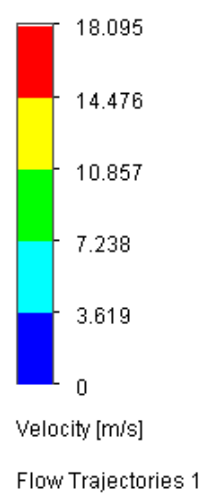

B

As can be seen in the images above, the fan with flat fins and face parallel to the fan axis (A) showed a more efficient fluid flow compared to the concave fins fan and the base also parallel to the fan axis (B) - configuration that presented the best performance among the others with concave fins. This was due to the air flow falling more directly on the hot parts of the CVT, where heat will be generated due to friction, thus enabling a greater and more marked reduction in the temperature of these components.

Then, after defining the fin geometry to be used, the second series of analyzes was made, aimed at defining the ideal number of fins from the analysis of the temperature reduction in 10 seconds. Thus, the values shown in Table 2 were obtained, and it is possible to generate the Figure 4, representing the average temperature reduction in relation to the number of fins used. 
Table 2. Data obtained in the simulations - Series 1

\begin{tabular}{|c|c|c|c|c|c|}
\hline $\begin{array}{l}\text { Number } \\
\text { of fins }\end{array}$ & $\begin{array}{c}\text { Final } \\
\text { Temperature } \\
\text { of Simulation } \\
1\left({ }^{\circ} \mathrm{C}\right)\end{array}$ & $\begin{array}{c}\text { Final } \\
\text { Temperature } \\
\text { of Simulation } \\
2\left({ }^{\circ} \mathrm{C}\right)\end{array}$ & $\begin{array}{c}\text { Final } \\
\text { Temperature } \\
\text { of Simulation } \\
3\left({ }^{\circ} \mathrm{C}\right)\end{array}$ & $\begin{array}{c}\text { Average } \\
\left({ }^{\circ} \mathrm{C}\right)\end{array}$ & $\begin{array}{l}\text { Reduction } \\
\left({ }^{\circ} \mathrm{C}\right)\end{array}$ \\
\hline 7 & 79,7876 & 79,7885 & 79,7856 & 79,7872 & 0,2128 \\
\hline 8 & 79,7956 & 79,7965 & 79,7985 & 79,7969 & 0,2031 \\
\hline 9 & 79,7749 & 79,7794 & 79,7791 & 79,7778 & 0,2222 \\
\hline 10 & 79,7806 & 79,7808 & 79,7823 & 79,7812 & 0,2188 \\
\hline 11 & 79,7859 & 79,7894 & 79,7862 & 79,7872 & 0,2128 \\
\hline 13 & 79,7851 & 79,7851 & 79,7711 & 79,7787 & 0,2213 \\
\hline 14 & 79,7698 & 79,7736 & 79,7666 & 79,7758 & 0,2300 \\
\hline 15 & 79,7723 & 79,7748 & 79,7749 & 79,7745 & 0,2260 \\
\hline 16 & 79,7769 & 79,7795 & 79,7824 & 79,7796 & 0,2204 \\
\hline 17 & 79,7705 & 79,7625 & 79,7657 & 79,7662 & 0,2338 \\
\hline 18 & 79,7867 & 79,7694 & 79,7716 & 79,7759 & 0,2241 \\
\hline
\end{tabular}

Figure 4. Temperature reduction by number of fins - Series 1

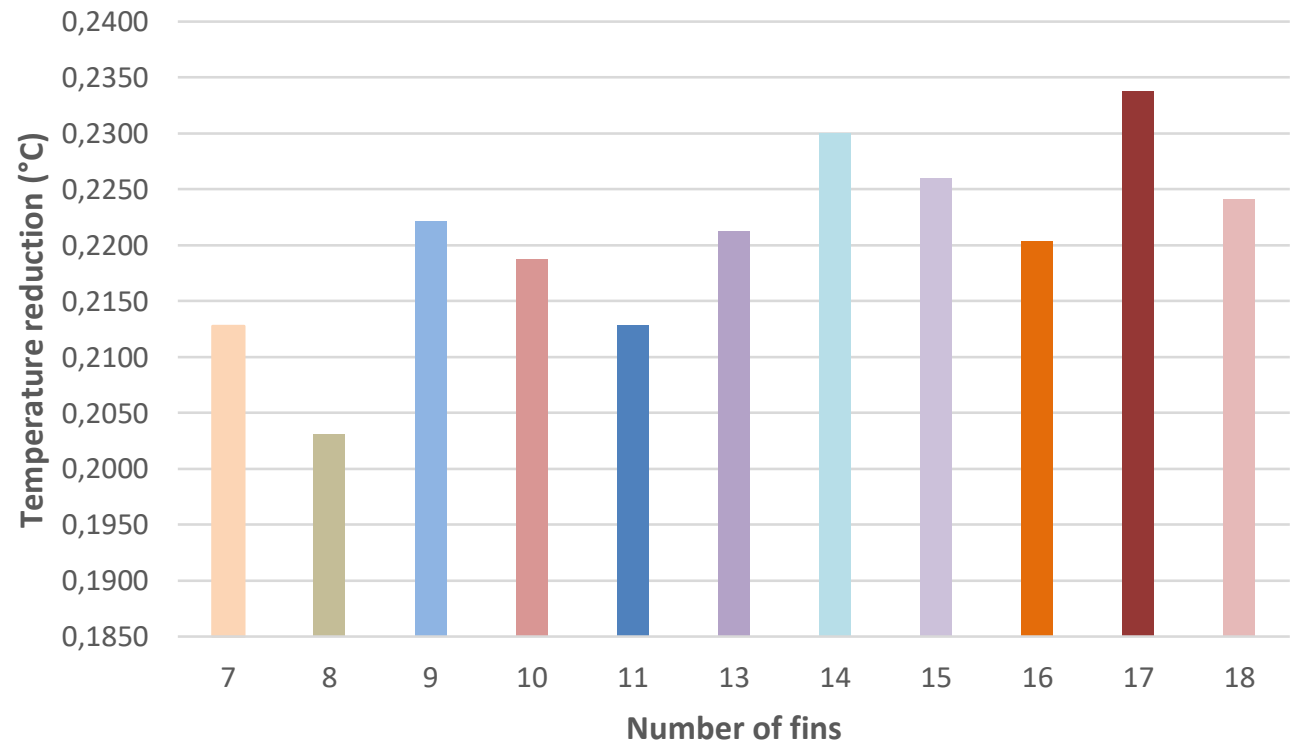


Analyzing the results above, it is possible to notice that there is a considerable influence of the amount of fan fins on the cooling rate. However, due to the absence of a direct relationship between the factors and the short period of time for each analysis, it was not possible to conclude with precision which would be the best fan model. Therefore, the four best fans were selected so that another series of simulations can be made for each model.

Thus, using fans with 14, 15, 17 and 18 fins, new simulations were performed, again in triplicate, increasing the physical time to $120 \mathrm{~s}$, allowing the complete development of the fan speed, since the pulley rotates at $1500 \mathrm{Rpm}$ and consequently, complete circulation and maximum fluid speed inside the cover. Table 3 presents the data obtained in the analyzes and Figure 5 shows the averages obtained in relation to the number of fins.

Table 3. Data obtained in the simulations - Series 2

\begin{tabular}{|c|c|c|c|c|c|}
\hline $\begin{array}{l}\text { Number } \\
\text { of fins }\end{array}$ & $\begin{array}{c}\text { Final } \\
\text { Temperature } \\
\text { of Simulation } \\
1\left({ }^{\circ} \mathrm{C}\right)\end{array}$ & $\begin{array}{c}\text { Final } \\
\text { Temperature } \\
\text { of Simulation } \\
2\left({ }^{\circ} \mathrm{C}\right)\end{array}$ & $\begin{array}{c}\text { Final } \\
\text { Temperature } \\
\text { of Simulation } \\
\mathbf{3}\left({ }^{\circ} \mathbf{C}\right)\end{array}$ & $\begin{array}{l}\text { Average } \\
\left({ }^{\circ} \mathrm{C}\right)\end{array}$ & $\begin{array}{l}\text { Reduction } \\
\quad\left({ }^{\circ} \mathrm{C}\right)\end{array}$ \\
\hline 17 & 72,9477 & 72,7422 & 72,7492 & 72,8130 & 7,1870 \\
\hline 14 & 73,4228 & 73,1418 & 73,1065 & 73,2237 & 6,7763 \\
\hline 15 & 73,2896 & 73,4221 & 73,6902 & 73,4673 & 6,5327 \\
\hline 18 & 73,0668 & 73,004 & 72,8656 & 72,9788 & 7,0212 \\
\hline
\end{tabular}

Figure 5. Temperature reduction by number of fins - Series 2

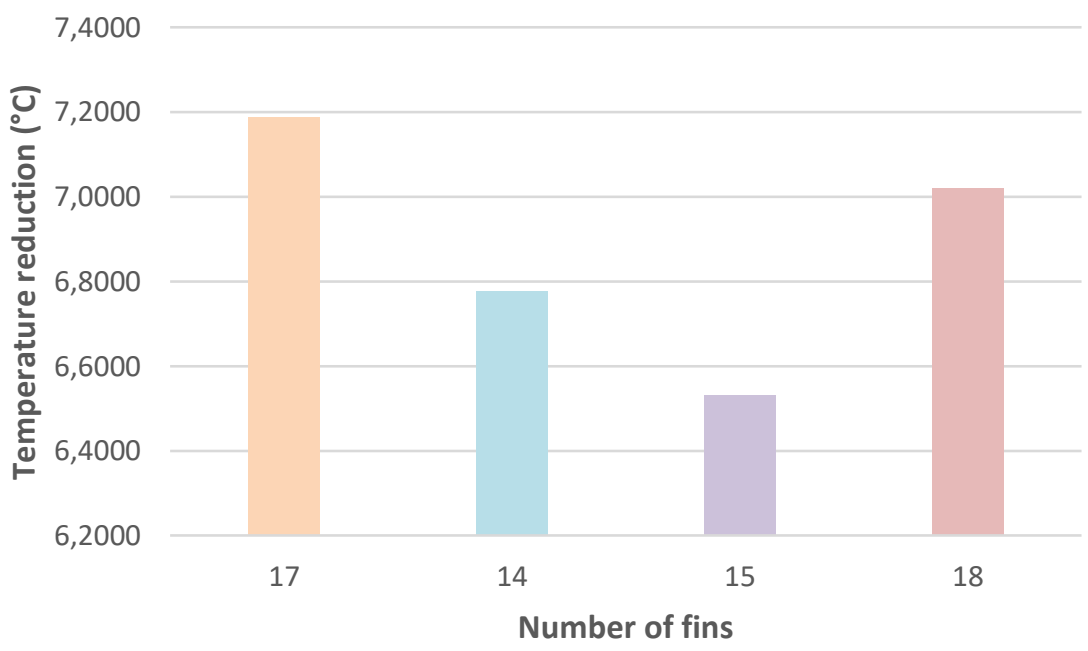




\section{CONCLUSION}

From the first series of analyzes, a prior selection of the best modeled fan configurations was made. In this way, simulations were carried out with a longer physical time, in order to obtain more realistic results.

Analyzing the final results, it was identified that the fan with 17 fins has a better performance compared to the other models, presenting an average reduction of 7.18 ${ }^{\circ} \mathrm{C}$ in 120 seconds.

For future studies it is important to carry out analyzes with longer physical times, as well as with input data obtained from practical analyzes, such as heat generation due to friction, thus obtaining a simulation with greater precision.

\section{REFERENCES}

1 LECHNER, Gisbert; NAUNHEIMER, Harald; RYBORZ, Joachim. Automotive Transmissions: Fundamentals, Selection, Design and Application. Springer, 1999.

2 MARTINS, Lucas Isla. Modelagem de Transmissão Continuamente Variável de um Veículo Off-road. Monografia (Graduação em Engenharia Mecânica), Escola de Engenharia de São Carlos da Universidade de São Paulo, 2018.

${ }^{3}$ MATILDE, Luciana Heringer. Desenvolvimento e Validação Experimental de Modelo Matemático de Transmissão Continuamente Variável (CVT) para Veículo Fora de Estrada BAJA SAE. Departamento de Engenharia Mecânica, PUC-RIO, 2018.

${ }^{4}$ VERSTEEG, H. K.; MALALASEKERA, W. An Introduction to Computational Fluid Dynamics. Second Edition. Person Education Limited, 2007.

5 PEREZ, Nestor Proenza. Sistemas Fluidomecânicos: Classificação dos Ventiladores. Disponível em: <https://www.feg.unesp.br/Home/PaginasPessoais/nestorproenzaperez/sfm-2014-aula-23.pdf>. Accessed on: JUL 20. 2020.

${ }^{6}$ BRESOLIN, João Guilherme. Avaliação da Eficiência do Sistema de Transmissão Utilizado em Protótipos BAJA SAE. Monografia (Graduação em Engenharia Mecânica), Escola Engenharia da Universidade Federal do Rio Grande do Sul, Porto Alegre, 2012. 